\title{
Аналіз конструкцій і вибір складально-зварювальних пристосувань для виготовлення малогабаритних машин із виробництва будівельних матеріалів і конструкцій
}

\author{
Полтавський національний технічний університет \\ імені Юрія Кондратюка
}

\begin{abstract}
Наведено результати досліджень 3 аналізу конструкції та вибору складальнозварювальних пристосувань для виготовлення малогабаритних машин із виробництва будівельних матеріалів і конструкцій різного призначення. Одночасно постійно зростаючі вимоги щодо скорочення термінів освоєння нового обладнання та підвищення їх якості при мінімальних трудових і матеріальних витратах привели до достатнього прогресу в розвитку конструкції технологічного складального оснащення при проведенні зварювальних робіт.

Як показав аналіз і практика в умовах багатономенклатурного виробництва при дискретно-нестабільних програмах випуску виробів для технічного оснащення зварювальних операцій доцільно застосовувати замість нероз'ємних зварювальних пристосувань універсальні складально-зварювальні переналагоджувані пристосування багаторазового використання. Ці пристосування складаються з набору конструктивноуніфікованих елементів, із яких шляхом відповідного багаторазового компонування або перекомпонування створюються різні спеціальні пристосування для складання різноманітних зварних конструкцій.

Можливість такого компонування та перекомпонування елементів таких пристосувань забезпечується високою взаємозамінністю й універсальністю їх конструкції. Причому встановлені стандартами норми й точності та взаємне розташування поверхонь елементів забезпечують їх складання без натягів і подальшої підгонки.

Універсальні переналагодждувальні пристосування мають значні переваги в точності та надійності виготовлення зварювальних виробів різних габаритних розмірів і конфігурацій. Доцільно для виробництва машин із виготовлення будівельних матеріалів і конструкцій використовувати універсальні збірно-розбірні переналагоджувані пристосування.
\end{abstract}

Ключові слова: машина змішувальна, зварювальне нерозбірне пристосування, зварювальні збірно-розбірні переналагоджувані пристосування.

\section{Постановка проблеми}

У будівництві залишається значна частина робіт 3 ремонту та реконструкції діючих будівельних об'єктів, а також при створенні малоповерхових будинків, що потребує їх створення та застосування малогабаритного обладнання для виготовлення будівельних матеріалів і конструкцій, а саме змішувальних установок для отримання різних будівельних сумішей (бетонних, штукатурних і т.п.).

Створення такого типу обладнання дає можливість ефективно та легко механізувати важкі операції, пов'язані 3 приготуванням і використанням будівельних сумішей різного призначення на невеликих об'єктах.

Одночасно постійно зростаючі вимоги щодо скорочення термінів освоєння нового обладнання та підвищення їх якості при мінімальних трудових i матеріальних витратах привели до достатнього прогресу в розвитку конструкцій технологічного оснащення, наприклад, при проведенні складальнозварювальних робіт вузлів устаткування.

Подальший прогрес у створенні та розвитку складально-зварювальних 
пристосувань потребує науково обґрунтованого підходу до вибору конструктивного варіанта розроблених пристосувань.

Як підказала практика в умовах багатономенклатурного виробництва при дискретно-нестабільних програмах випуску виробів для технічного оснащення зварювально-складальних операцій доцільно застосовувати різні спеціальні пристосування.

Мета роботи: провести аналіз конструкцій і тенденцій розвитку складально-зварювальних пристосувань, а також визначити найбільш прийнятні серед них для виготовлення малогабаритних будівельно-змішувальних пристосувань різного призначення.

\section{Основний матеріал}

За ступенем спеціалізації, конструктивним оформленням і методами виконання складально-зварювальні пристосування, що застосовують у даний час, можна розділити на нерозбірні спеціальні (НСП), універсальнобезналагоджувальні (УБП), спеціалізовані налагоджувальні $(\mathrm{CHП)} \mathrm{і}$ універсально-збірні (УЗП).

У виробництві зварних конструкцій найбільше поширення отримали нерозбірні спеціальні пристосування. Вони з різним ступенем ефективності використовуються у всіх видах виробництв і займають домінуюче положення $30 \ldots 40$ \% від загальної маси інших пристосувань, що застосовуються.

НСП $€$ засобом технологічного оснащення великосерійного і середньосерійного виробництва. В одиничному і дрібносерійному виробництві їх використовують у разі конечної потреби - коли без пристосувань неможливо забезпечити задану точність виготовлення зварних конструкцій.

Літературний аналіз [1 - 3] показав, що НСП $є$ пристосуваннями одноцільового призначення і являють собою необоротні пристрої, що розробляються і виготовляються в індивідуальному порядку. Конструктивно вони складаються 3 елементів (деталей і пристроїв) різного функціонального призначення, певним чином об'єднуються в цілісні, іноді нерозбірні конструкції, яким властиве різноманіття варіантів виконання.

Із розглянутих робіт видно, що у складі НСП переважають прості за конструкцією елементи. Основи пристосувань виготовляють у більшості випадків зварними з листового і профрільного прокату з використанням у певних місцях опорних платиків. Встановлювані, фріксуючі й затискні елементи виконуються швидкодіючими у вигляді шарнірно-важільних, поворотних, відкидних та їм подібних пристроїв з гвинтовим або ексцентриковим виконавчим механізмом.

Говорячи про конструкції НСП у цілому, автори ряду робіт відзначають, що їх розробляють 3 урахуванням конструктивно-технологічних особливостей конкретних зварних вузлів та, як правило, добре поєднують 3 їх формами, забезпечуючи зручне встановлення та надійне закріплення заготовок, вільний доступ до місць прихоплювача та зварювання, безперешкодне виймання готових вузлів із пристосувань.

Аналіз конструкторської документації показав, що елементи НСП виготовляють у більшості випадків із низьколегованих вуглецевих сталей без подальшої термічної обробки. Робочі поверхні пристосувань виконують за 11 12 квалітетами (ГОСТ 25347-2013) з шорсткістю поверхонь Ra 1,6 - 12,5 мкм за 
ГОСТ 2789-73. Допуски фрорми та розташування робочих поверхонь відповідають 9-11 ступеням точності за ГОСТ 24643-81. Решту поверхонь виконують вільними з шорсткістю, що відповідає стану поставки вихідного матеріалу.

Зважаючи на це, НСП технологічні і відносно дешеві у виготовленні, прості й зручні в експлуатації. Застосування беззазорного (пальцевого) або зварного варіантів з'єднань елементів пристосувань забезпечує їм високу жорсткість при мінімальній металоємності, здатність тривалого збереження сталості розмірів, надає раціональні фрорми та компактність їх конструкціям, що й обумовило широке застосування спеціальних пристосувань.

Проте разом із перевагами НСП мають ряд суттєвих недоліків, що багато в чому обумовлюють їх невідповідність вимогам і темпам сучасного технічного процесу.

Основним недоліком НСП, на думку автора [4], $€$ їх одноцільове призначення та неможливість переналаштування на виробництво інших виробів, конструктивно відмінних від тих, для яких вони розроблені. Причини цього полягають в індивідуальному підході до проектування спеціальних пристосувань, використанні в їх конструкціях оригінальних рішень, беззазорних і нероз'ємних з'єднань елементів, у результаті чого в конструкціях НСП практично відсутні уніфріковані й стандартні елементи, наділені взаємозамінністю та можливістю повторного застосування, що забезпечують оборотність пристосувань.

За даними ряду робіт [2, 5], рівень уніфікації та стандартизації елементів НСП становить 25...30 \%, причому більше половини його припадає на кріпильні елементи. Це зумовлює необхідність виробництва спеціальних пристосувань в інструментальних цехах підприємств, оскільки організація спеціалізованого виробництва широкої номенклатури елементів НСП нерентабельна. Такий шлях потребує великих витрат і $€$ малоефективним з огляду на те, що продуктивність праці в інструментальних цехах підприємств в 2-3 рази нижча, ніж у спеціалізованому виробництві. Підвищення ефективності спеціальних пристосувань автори зазначених робіт бачать у стандартизації елементів пристосувань, що часто зустрічаються. За їхнім задумом стандартні елементи мають зніматися з відпрацьованих пристосувань і використовуватися повторно у нових конструкціях НСП, крім цього, такі елементи можна виготовляти партіями із застосуванням методів серійного виробництва, що дасть позитивний ефект.

Індивідуальний характер розроблення спеціальних пристосувань не дає можливості належним чином використовувати висопродуктивне обладнання та передову технологію для їх виготовлення. У результаті цього одержувана точність елементів НСП не забезпечує повної їх взаємозамінності, а довговічність - можливості повторного використання.

Таким чином, незважаючи на простоту і компактність конструкцій, зручність і надійність в експлуатації, спеціальні пристосування не мають достатньої для умов прискореного науково-технічного прогресу гнучкості. У результаті при зміні об'єктів виробництва їх списують, іноді задовго до зносу, а при освоєнні нових виробів проектують і виготовляють заново. Це потребує значних витрат і не забезпечує повної віддачі коштів, вкладених у створення НСП.

Вирішення задач, спрямованих на вдосконалення технологічної підготовки виробництва зварних конструкцій, привело до створення та запровадження переналагоджуваних пристосувань багаторазового застосування, до яких, у 
першу чергу, слід віднести УЗП, що добре зарекомендували себе у зварювально-складальному одиничному та дрібносерійному виробництвах. На їх базі були розроблені та впроваджені конструктивно-різноманітні набори елементів універсально-збірних пристосувань для складально-зварювальних робіт (УЗП) [6 - 7, 8].

УЗП складаються з набору конструктивно уніфікованих елементів (рис. 1), із яких шляхом відповідального багаторазового компонування i перекомпонування створюються спеціальні пристосування для збирання різноманітних зварних конструкцій. Можливість такого компонування і перекомпонування елементів УЗП забезпечується високою взаємозамінністю та універсальністю їх конструкцій. Причому встановлені стандартами норми точності й взаємного розташування поверхонь елементів УЗП забезпечують їх збирання без натягів та подальшої підгонки.

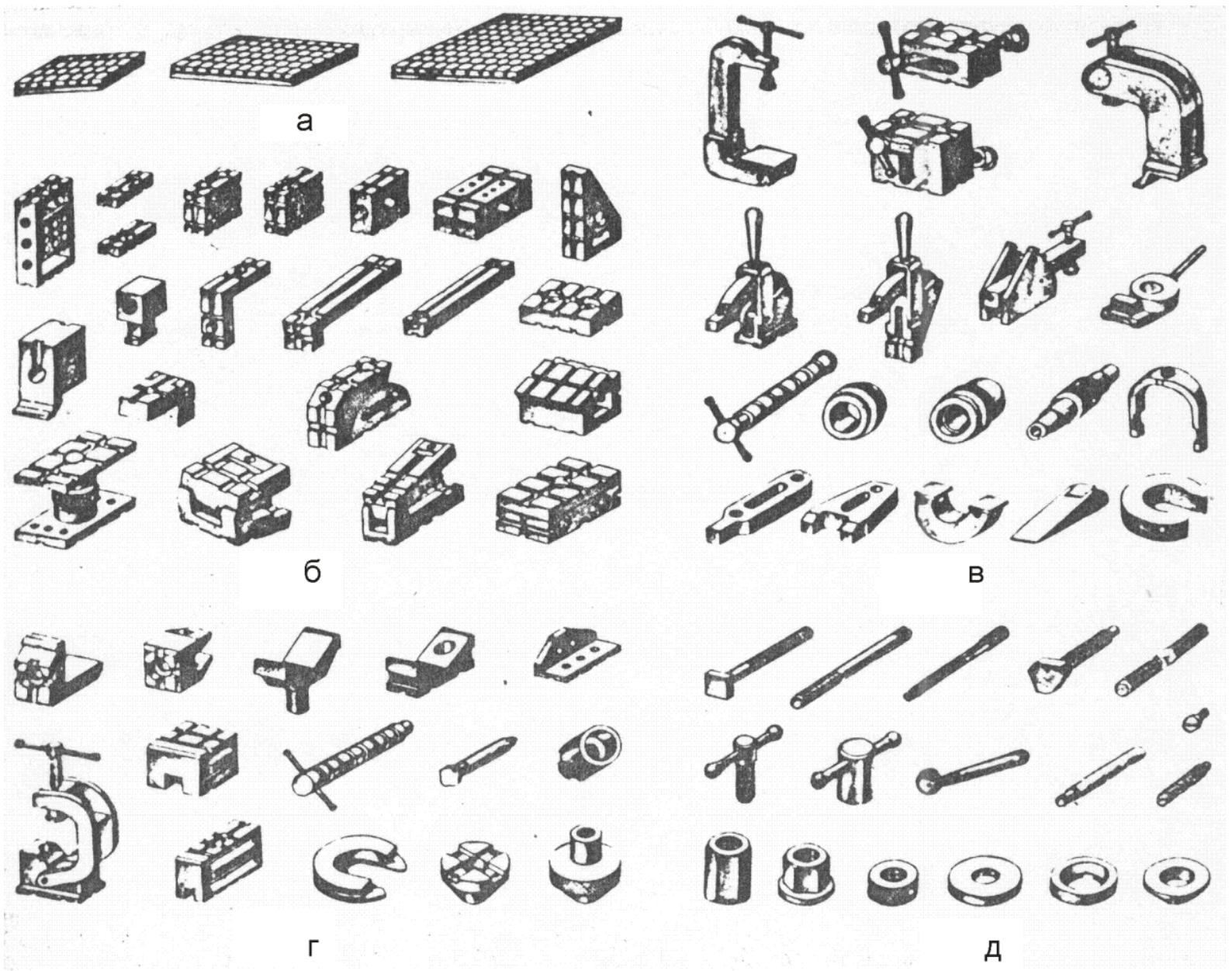

Рис. 1. Основні групи елементів УЗП:

а - базові; б - опорно-конкурсні; в - фріксуючі; г - притискні;

д - кріпильні елементи

Для забезпечення багаторазового і тривалого використання елементи УЗП виготовляють в основному з хромистих конструкційних та інструментальних сталей (20X, 40X, 38XА, У8, У12 та ін.), їх піддають відповідній термообробці (від 38 до 62 одиниць за Роквеллом на поверхні) та покривають спеціальними захисними покриттями, що захищають їх від стираючих впливів і бризок 
розплавленого металу. Все це забезпечує надійну роботу елементів УЗП протягом $10-12$ років [2, 3, 5, 6] і, незважаючи на високу вартість елементів УЗП, витрати на їх виготовлення окупаються протягом $1-1,5$ року.

Характерною особливістю елементів УЗП $€$ наявність в їх конструкції Тподібних і шпонкових пазів, гладких і різьбових отворів, за допомогою яких елементи з'єднують між собою болтами, шпильками і гайками, утворюючи при цьому компонування пристосування (рис. 2), взаємну фріксацію елементів, які поєднують. Це гарантує певну свободу при збиранні пристосувань і забезпечує їм належну жорсткість.
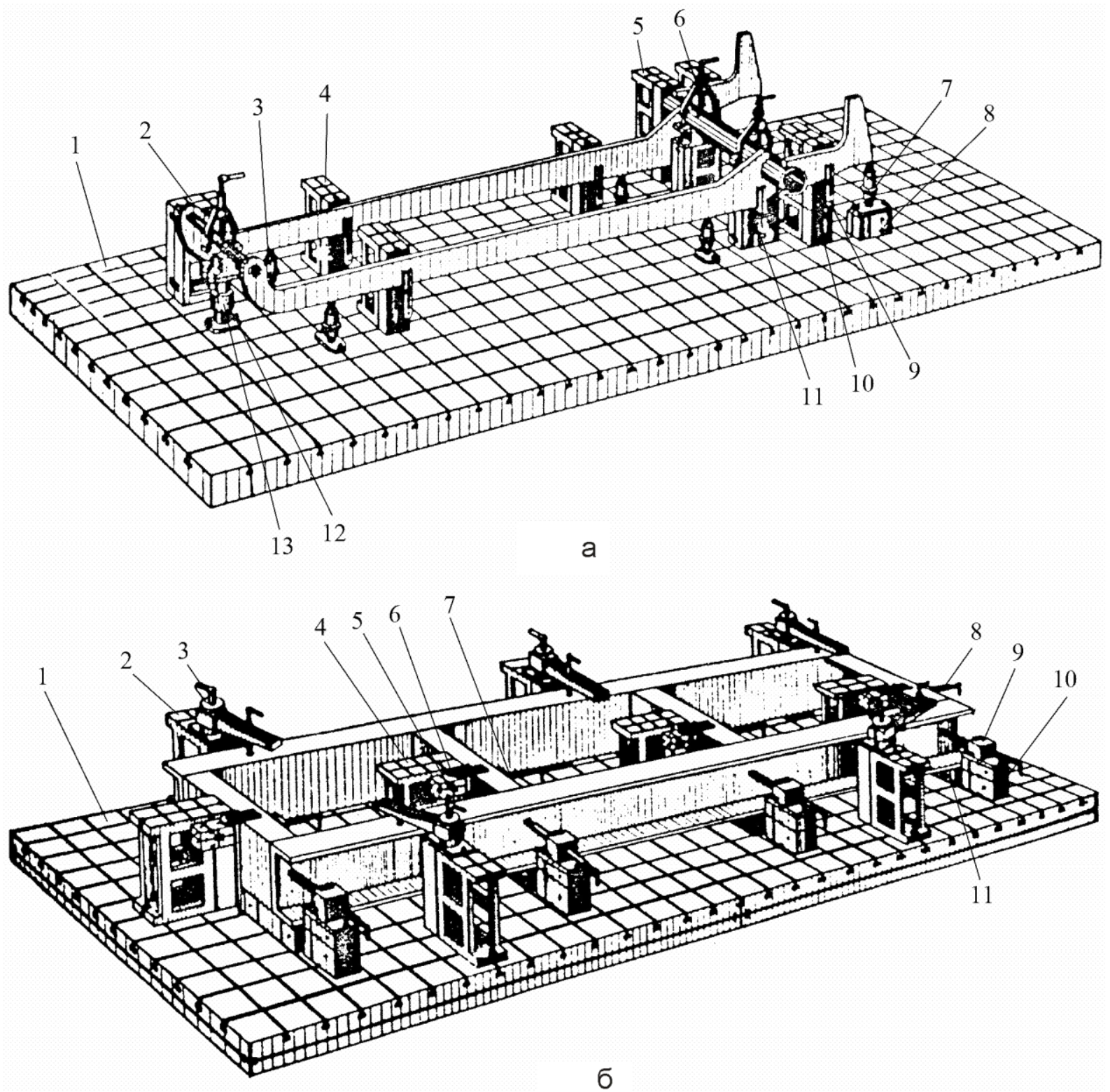

Рис. 2. Принципова конструкція УЗП:

а - компонування УЗП для збирання важеля; б - компонування УЗП для збирання рами; 1-13 - елементи різних груп УЗП

Таким чином, УЗП, з одного боку, являють собою більш гнучку порівняно 3 НСП систему технологічного оснащення, що дозволяє в найкоротші строки 
отримувати необхідні пристосування та швидко їх переналагоджувати при зміні вимог виробництва без відволікання на це потужностей інструментальних цехів, які застосовують в умовах серійного виробництва.

Проте, звертаючись до досвіду експлуатації НСП у складальнозварювальному виробництві, слід зазначити, що область і обсяги застосування подібних пристосувань у складально-зварювальному виробництві досить обмежені можливістю групування зварних конструкцій і типізації технологічних процесів їх виготовлення, як необхідних умов ефективного використання НСП.

\section{Висновки}

1. Складально-зварювальні пристосування, що застосовують у цей час, маючи певні переваги і властиві їм недоліки, повною мірою не забезпечують успішної діяльності підприємств в умовах інтенсивного розвитку наукового прогресу, підвищення вимог до точності й надійності виробів, частої їх змінюваності та необхідності освоєння нових видів продукції у найкоротший термін.

2. У розвитку конструкцій твердо намітилися тенденції пререходу від нерозбірних одноцільових пристосувань багаторазового застосування УЗП, що дозволяє значно знизити витрати і терміни підготовки виробництва.

3. Доцільно для виготовлення машин із виробництва будівельних матеріалів і конструкцій застосовувати універсально-збірні пристосування.

\section{Список литературы}

1. Крампит, Н. Ю. Сварочные приспособления [Текст] / Н. Ю. Крампит, А. Г. Крампит. - Юрга: ЮТИ ТПУ, 2008. - 95 с.

2. Разжигаев, А. Ф. Сборочно-сварочные приспособления. Брошюра [Текст] / А. Ф. Разжигаев. - Москва-Свердловск: Машгиз, 1960. - 51 с.

3. Филатов, Л. С. Система переналаживаемой технологической оснастки для сборочно-сварочного производства отрасли [Текст] / Л. С. Филатов // Прогрессивные виды универсально-сборной переналаживаемой оснастки: тез. докл. ІІ отраслевой конф. - М., 1987. - С. 20 - 25.

4. Артемьев, И.Д. Универсально-сборные приспособления для сварочных и паяльних работ [Текст] / И. Д. Артемьев // Сварочное производство. № 4.- 1967. - С. $34-36$.

5. Пономарев, В.А. Универсально-сборные приспособления для сборочносварных работ [Текст] / В. А. Пономарев, И. С. Чугунихин, Ю. В. Бородин. М.: Машиностроение, 1981. - 152 с.

6. Полякова, Д. И. Переналаживаемая технологическая оснастка [Текст] / под. ред. Д. И. Полякова. - М.: Машиностроение, 1988. - 456 с.

7. Жолткевич, Н. Д. Отраслевая система переналаживаемой технологической оснастки для ускорения технологической подготовки производства [Текст] / Н. Д. Жолткевич и др. - М.: ЦНИИ информ., 1988. - 248 с. 
8. Универсальные сборно-разборные приспособления для сборочносварочных работ [Текст] / А. Я. Мовшович, М. Е. Федосеева, Ю. А. Черная, О. В. Бондарь // Открытые информационные и компьютерные технологии: сб. науч. тр. Нац. аэрокосм. ун-та им. Н. Е. Жуковского «ХАИ». - Вып. 60. X., 2013. - C. $42-45$.

\section{References}

1. Krampit, N. Ju. Svarochnye prisposoblenija [Reference device]. Jurga: JuTI TPU. 2008. 95 p.

2. Razzhigaev, A. F. Sborochno-svarochnye prisposoblenija. Broshjura [Assemblywelding devices. Brochure]. Moskva-Sverdlovsk: Mashgiz. 1960. 51 p.

3. Filatov, L. S. Sistema perenalazhivaemoj tehnologicheskoj osnastki dlja sborochno-svarochnogo proizvodstva otrasli [The system of retrofitted tooling for the assembly and welding industry production]. Progressivnye vidy universal'nosbornoj perenalazhivaemoj osnastki: tez. dokl. Il otraslevoj konf [Progressive types of the universal modular retrofitted rigging: theses of the report of the II sectoral conference]. M, 1987, pp. $20-25$.

4. Artem'ev, I. D. Universal'no-sbornye prisposoblenija dlja svarochnyh i pajal'nih rabot [Universal assembled devices for welding and soldering]. Svarochnoe proizvodstvo [Welding production]. no. 4, 1967, pp. 34 - 36.

5. Ponomarev, V. A, Chugunihin, I. S., Borodin, Ju. V. Universal'no-sbornye prisposoblenija dlja sborochno-svarnyh rabot [Universal assembled assembly and welding devices]. M.: Mashinostroenie, 1981, 152 p.

6. Poljakova, D. I. Perenalazhivaemaja tehnologicheskaja osnastka [Retrofit tooling]. M.: Mashinostroenie, 1988, 456 p.

7. Zholtkevich, N. D. i dr. Otraslevaja sistema perenalazhivaemoj tehnologicheskoj osnastki dlja uskorenija tehnologicheskoj podgotovki proizvodstva [Sectoral system of retrofitted tooling to accelerate the technological preparation of production]. M.: CNII inform., 1988, 248 p.

8. Movshovich, A. Ja., Fedoseeva, M. E., Chernaja, Ju. A., Bondar', O. V. Universal'nye sborno-razbornye prisposoblenija dlja sborochno-svarochnyh rabot [Universal collapsible devices for assembly and welding]. Otkrytye informacionnye i komp'juternye tehnologii: sb. nauch. tr. Nac. ajerokosm. un-ta im. N. E. Zhukovskogo "HAl»» [Proc. of the National aerospace university Kharkiv aviation institute "Open Information and Computer Integrated Technologies»], 2013, no. 60, pp. $42-45$. 


\section{The Analysis of Structures and Choice of Assembly-Welding Devices for the Manufacture of Small-Sized Machines for the Building Materials and Structures Production}

The results of investigations on the analysis of the design and choice of assembly-welding devices for the manufacture of small-sized machines for the building materials and various purposes production structures are presented. Simultaneously, the ever-increasing requirements to reduce the time needed for the development of new equipment and improve their quality with minimal labour and material costs led to sufficient progress in the development of the design of technological assembly equipment during assembly and welding.

As the analysis and practice have showen in multi-unit production conditions with discreteunstable production programs for the technical equipment of welding and assembly operations, it is advisable to use universal reusable assembly and welding re-adjustable fixtures instead of one-piece welding device. These devices consist of a set of structurally standardized elements from which various special devices for assembling a variety of welded structures are created by appropriate reusable composing or re-arranging.

The possibility of such linking and re-arranging of the elements of UAD is provided by the high interchangeability and universality of their design. Moreover, the norms and accuracy established by the standards and the relative position of the surfaces of the UAD elements ensure their assembly without tightness and further adjustment.

Assembly and welding devices UAD have significant advantages in accuracy and reliability of manufacture of welding and assembly products of various dimensions and configurations.

It is advisable for the production of machines for the manufacture of building materials and structures to use universal collapsible re-adjustable devices.

Key words: mixing machine, non-folding welding device, collapsible welding re-adjustable device.

\section{Відомості про авторів:}

Фролов Євген Андрійович - д-р техн. наук, профессор, профресор кафедри технології машинобудування ПНТУ, м Полтава, Україна; e-mail: frolov.poltntu@gmail.com; ORCID:0000-0002-2691-5386.

Коробко Богдан Олегович - д-р. техн. наук, доцент, доцент кафедри технології машинобудування ПНТУ, м. Полтава, Україна; e-mail: natavereck@ukr.net; ORCID: 0000-0001-5319-6615.

Кравченко Сергій Іванович - канд. техн. наук, доцент, доцент кафедри технології машинобудування ПНТУ, м Полтава, Україна; e-mail: 050Ser09@i.ua; ORCID: 0000-0003-3250-8645.

\section{About the Authors:}

Frolov Evgeniy Andreevych, Doctor of Technical Sciences, Professor, Head of the Department of mechanical engineering technology, Poltava National Technical Yuri Kondratyuk University, Poltava, Ukraine; email: frolov.poltntu@gmail.com; ORCID:0000-0002-2691-5386.

Korobko Bogdan Olegovich, Doctor of Technical Sciences, Associate Professor, Associate Professor of the Department of mechanical engineering technology, Poltava National Technical Yuri Kondratyuk University, Poltava, Ukraine; e-mail: natavereck@ukr.net; ORCID: 0000-0001-5319-6615.

Kravchenko Sergiy, PhD, Associate Professor, Poltava National Technical Yuri Kondratyuk University, Poltava, Ukraine; e-mail: 050Ser09@i.ua; ORCID: 0000-0003-3250-8645. 